\title{
Good Agricultural Practices in Protected Areas: Which factors Affecting the implementation?
}

\author{
Polyxeni Karagkiozi ${ }^{1, a}$, Eleni Oxouzi ${ }^{1, b, *}$, Evangelos Papanagiotou ${ }^{1, c}$ \\ ${ }^{1}$ Department of Agricultural Economics, School of Agriculture, Aristotle University of Thessaloniki, 15343 Athens, Greece \\ *Corresponding author

\begin{tabular}{l|l}
\hline A R T I C L E I N F O & A B S T R A C T \\
Research Article & $\begin{array}{l}\text { The purpose of this study is to indicate and analyse the factors that affect the decision of the Prespa } \\
\text { bean producers to implement Good Agricultural Practices (GAP) in their farmlands. Additionally, } \\
\text { the social characteristics of the producers are analyzed in order to obtain a broader picture. To } \\
\text { achieve the above objectives, a logit model was applied as well as descriptive statistics for the } \\
\text { analysis of the personal and social characteristics of farmers. The research was conducted in the } \\
\text { Florina Prefecture of Western Macedonia through questionnaires that were filled in during personal } \\
\text { interviews with the producers. The results of the research showed that growing PGI (Protected } \\
\text { Geographical Indication) products, attending training seminars, the educational level of the } \\
\text { producers, the earned income, the communication and information by an agricultural engineer affect } \\
\text { significantly the decision of the producers to apply Good Agricultural Practices. }\end{array}$ \\
$\begin{array}{l}\text { Keywords: } \\
\text { Logit model }\end{array}$ &
\end{tabular} \\ Logit model
}

Prespa bean

Good agricultural practices,

protected areas

Protected Geographical Indication

a Qxeniakarag@gmail.com

\section{Introduction}

Agricultural activity and the environment are strongly interconnected and they form direct interdependent bonds. The problems caused by common agricultural practices, with the use of pesticides and fertilizers, the exhaustion of farmland because of mistakenly maintained or harmful to the environmental balance management systems, even in the case of protected areas, have led to the need to search for new, environmentally friendly agricultural practices. Moreover, consumers are now focusing on non usual quality features of products, such as the origin, the production method, food safety and hygiene as well as the respect for the environment (Parra-Lopez et al., 2007). Consumers, retailers and governments are concerned about the quality, the food safety and the treatments during production as well (De Baerdemaeker, 2013)

In order to deal with these problems and sustain the positive outcomes of agriculture, the producers are now able to apply new practices called the Codes of Good Agricultural Practice (CoGAP). These Codes offer guidance on agricultural activities such as soil treatment and fertilization, plant protection, waste management, water management, crop rotation, harvest, pasture lands management, etc. These practices aim at the sustainable management of farmland and natural resources, the protection and preservation of the environment as well as the protection of the health of farmers and consumers (Ministry of Rural Development and Food, 2010).

The Codes of Good Agricultural Practice are implemented to areas that are very important to the surrounding ecosystems, because they affect them directly (Ministry of Rural Development and Food, 2010). These areas are deemed vital to the natural environment, and they must be protected legally and institutionally.

According to the International Union for the Conservation of Nature (IUCN), the term Protected Area designates the: "Clearly defined geographical space, recognised, dedicated and managed, through legal or other effective means, to achieve the long term conservation of nature with associated ecosystem services and cultural values." 
According to Huttunen and Peltomaa (2016) agroenvironment and good farming policies could enhance and change farmers' personal mental states and goals in relation to the environmental impact of their activities. An empirical study made by Vastola et. al (2017) in Collina Materana in Southern Italy showed that the conservation agriculture could be part of a viable agricultural sustainable model, which combines satisfaction of food needs and environment preservation, as best practices available to preserve the biodiversity are included.

According to the Greek legislation (L.1650/86), a Special Environmental Study is required (EПM) for the declaration of protected areas. The parts of the protected areas which are of special natural value are usually in the centre of the protected area, where the necessary protection measures become stricter zone after zone. The protected areas are subjected to management and operation regulations which define the necessary measures for the organization and operation of the protected objects in order to ensure, to a greater extent, objectivity, the provision for the natural environment and the investigation of the various results (L.3010/02, Joint Ministerial Decision No $11014 / 703 / \Phi 104 / 03)$. In Greece, there are many declared protected areas of different categories, most of which belong to a European network of protected areas (www.ypeka.gr). The regulations of good agricultural practices allow countries to use scientific knowledge and change their agri-environmental programs to increase their effectiveness (Battary et al., 2016).

In our country, one of the products being cultivated and produced within the boundaries of a protected area is the bean. Bean agriculture takes place mostly in Western Macedonia, in various parts of the above region. More specifically, the bean is the most important and most traditionally cultivated plant species in the area of the Prespa Lakes. It has also been registered as a Protected Geographical Indication (PGI) product. According to Tregear et al. (2007), Belletti, et al. (2017), Borowska (2010), Hajdukiewicz (2014), local traditional products may represent a profitable development resource, as they can incorporate and utilize many different local elements, combined with special, environmental and geomorphological features that are intertwined with this particular area.

Bean agriculture holds $22.5 \%$ of the National Park in the Prespa Lakes; therefore, it is one of the most important plant cultivations of the area in terms of environmental value. The Prespa National Park (Official Journal of the Hellenic Republic 19A/75), whose wetland is protected by the Ramsar Convention, is the largest of the ten official National Parks in Greece and includes forest areas as well. The Core Area of the Prespa National Park consists of 4900 hectares and the Buffer Area of 14570 hectares. The flora and especially the fauna of the Park are distinguished for their variety and, in most cases, the significance of the included endangered species (www.prespes.gr). The National Park is of great environmental value due to the diversity of the ecosystems and of their biotic community. The ecosystem must be protected in order to ensure the sustainable development and preservation of nature, as humans are highly dependent on their environment (ramsar.wetlands.org).
All the aforementioned elements result in the fact that good environmental practices as well as the registration of various areas as protected ones may raise environmental awareness and encourage efforts to improve the quality of the agricultural production.

Therefore, the study of the personal and social features of the bean producers as well as the identification of the factors that affect the decision of the producers to implement Good Agricultural Practices (G.A.P.) may contribute to the protection of the environment and to the preservation of the natural landscape.

\section{Research Methodology}

The research was carried out in the area of the Prespes Municipality of the Florina Prefecture, through questionnaires that the producers filled in during personal interviews. To make this research easier and more effective, two different questionnaires were created for the two different groups of the bean producers: those who apply Good Agricultural Practices and those who do not. The two questionnaires included the same or similar questions in order to cover all aspects of the research.

In the case of the bean producers that implement GAP, the whole population was studied, that is 41 producers according to the archives of the Agricultural Cooperative "Pelekanos" and the Union of Agricultural Cooperatives of the Florina Prefecture. In addition, an equal in number sample of non-environmentally sensitive producers of the neighbouring cultivations was used.

The Primary Data were analysed in the "SPSS 17.0 Statistics," where descriptive statistics measures were used for studying the personal features of the producers. The logit model was used to indicate the factors that affect the decision of the producers to apply or not Good Agricultural Practices, and it was estimated by the "Stata 9" econometrics program.

The binary choice of adopting new technologies or innovations (in our case the choice of implementing or not GAP) can be described by the following probability function (cumulative probabilities distribution function) which gives the adoption probability (AP) (Cramer, 2004, Gujarati, 2003, Greene, 2000):

$$
\mathrm{AP}=\mathrm{P}\left(\mathrm{Y}_{\mathrm{i}}=1\right)=1 /\left(1+\mathrm{e}^{-\left(\beta_{0}+\beta_{1 \mathrm{x} 1}+\ldots \beta_{\mathrm{ixi}}\right)}\right.
$$

According to Relation (1), if $\mathrm{P}$ is the probability of adopting new technology -innovation, then $1-\mathrm{P}$ is the probability of not adopting such technology - innovation as shown in the following Relation:

$$
1-\mathrm{P}_{\mathrm{i}}=1 / 1+\mathrm{e}^{\mathrm{Z}_{\mathrm{i}}}
$$

Consequently, Relations (1) and (2) result in the following:

$$
\frac{\mathrm{P}\left(\mathrm{Y}_{\mathrm{i}}=1\right)}{\left(1-\mathrm{P}\left(\mathrm{Y}_{\mathrm{i}}=1\right)\right)}=\frac{1+\mathrm{e}^{\mathrm{Z}_{\mathrm{i}}}}{1+\mathrm{e}^{-\mathrm{Z}_{\mathrm{i}}}}=\mathrm{e}^{\beta_{0}+\beta_{1 \times 1}+\ldots+\beta_{\mathrm{ixi}}}
$$

Where $\mathrm{P}\left(\mathrm{Y}_{\mathrm{i}}=1\right) /\left(1-\mathrm{P}\left(\mathrm{Y}_{\mathrm{i}}=1\right)\right)$ is the odds ratio, that is the adoption probability to the non-adoption probability, the ratio being modified in every modification of the $\mathrm{X}_{\mathrm{i}}$ independent variables. 
The logit modification of the adoption probability $\mathrm{P}\left(\mathrm{Y}_{\mathrm{i}}=1\right)$ can be denoted as (Cramer, 2004, Cujarati, 2003):

$$
\mathrm{L}_{\mathrm{i}}=\log \left[\mathrm{P}\left(\mathrm{Y}_{\mathrm{i}}=1\right) /\left(1-\mathrm{P}\left(\mathrm{Y}_{\mathrm{i}}=1\right)\right)\right]=\mathrm{Z}
$$

Where $\log \left[\mathrm{P}\left(\mathrm{Y}_{\mathrm{i}}=1\right) /\left(1-\mathrm{P}\left(\mathrm{Y}_{\mathrm{i}}=1\right)\right)\right]$ is the logarithm of the odds ratio. In this way, the odds ratio logarithm becomes a linear function of the $\mathrm{X}_{\mathrm{i}}$ independent variables and our model changes from a classic linear (as to the parameters) to a regression model. The model is estimated in terms of econometrics in order to get the $\beta_{\mathrm{i}}$ coefficients.

In addition, we used the Hosmer and Lemeshow $\hat{C}$ test for the goodness of fit estimation. The statistical $\hat{\mathrm{C}}$ is considered to be distributed according to the Pearson's $\chi^{2}$ distribution. The $\chi^{2}$ value corresponding to the significance level $\alpha>0.05$ proves that the logistic regression model is well fitted to the data.

Finally, an additional measure for the goodness of fit estimation of the Logit model is the correct classification of observations between the different groups (GAP producers and non-GAP producers). This measure includes the number of observations made correctly and erroneously, based on the probability of an incidence (i.e. GAP application and no GAP application). If the estimating probability is higher than 0.5 , then the cultivator has implemented GAP; on the other hand, if the probability is lower than 0.5, the cultivator has not applied GAP (Siardos, 2000).

\section{Results}

\section{Descriptive Statistics Results}

According to the results of the research, the producers that implemented GAP were farmers by profession, they had completed 11.3 years of education on average and they were no more than 40 years old on average. Most of them were members of an agricultural cooperative or a group of producers, they had 18 years of agricultural experience on average, and they had attended seminars on agriculture.

Family tradition, the satisfactory income earned and the different way of living were the most important motives for those producers to work in the primary sector. Their cultivated land was from 0.12 up to 28 hectares large, 8.64 hectares being the average size.

As regards the personal features of the bean producers that did not apply GAP, all of them were farmers by profession, they had completed 6.7 years of education on average, and they were 51.1 years old on average. It is worth mentioning that the majority of these producers were not members of an agricultural cooperative or a group of producers, they had 25 years of agricultural experience on average, and they had never attended seminars on agriculture.

Family tradition, the satisfactory income earned and the different way of living were the most important motives for them to become farmers, as the case was with the GAP producers. Their farmland was from 0.10 up to 19 hectares large, the 6.26 hectares being the average size.

\section{Logit Model for Designating the Factors}

The logit model for the estimation of factors that affect the probability of implementing GAP in a protected area (the National Park) is formed as follows:

$$
\mathrm{Z}=\beta_{0}+\beta_{1} \mathrm{~T}+\beta_{2} \mathrm{~A}+\beta_{3} \mathrm{E}+\beta_{4} \mathrm{C}+\beta_{5} \mathrm{~S}+\beta_{6} \mathrm{~F}+\beta_{7} \mathrm{AI}
$$

Where;

$\mathrm{Z}=\log \left[\mathrm{P}\left(\mathrm{Y}_{\mathrm{i}}=1\right) /\left(1-\mathrm{P}\left(\mathrm{Y}_{\mathrm{i}}=1\right)\right)\right], \mathrm{T}=$ Type, $\mathrm{A}=$ Age,

$\mathrm{E}=$ Education, $\mathrm{C}=$ Communication, $\mathrm{S}=$ Seminars,

$\mathrm{F}=$ Family Tradition, AI= Agricultural Income

The variables used in the logit model are described in the following table (Table 1).

\section{Estimation of the Logit Model and Comments on the} Results

The following table (Table 2) presents the descriptive statistics results and, more specifically, the mean values and standard deviation of the independent variables incorporated in the logit model for both categories of the producers (i.e. GAP or non-GAP producers).

Table 1 Definition of variables used in the logit model

\begin{tabular}{l|ll}
\hline \multicolumn{1}{c}{ Dependent variable } & \multicolumn{1}{c}{ Category } \\
\hline Implementation of GAP & Binary & $1=$ Yes, $0=$ No \\
\hline \multicolumn{3}{c}{ Independent variables } \\
\hline Type & Binary & $1=$ producers certifying their product as PGI, $0=$ Other \\
Age & Continuous & Age in years \\
Education & Continuous & In years \\
Communication & Binary & $1=$ frequent consultation with an agricultural engineer, $0=$ Other \\
Seminars & Binary & $1=$ they have attended seminars, $0=$ Other \\
Family Tradition & Binary & $1=$ they have family tradition in agriculture, $0=$ Other \\
Agricultural Income & Continuous & Bean agriculture income $(€)$ \\
\hline
\end{tabular}

Table 2 Descriptive statistics of the sample ( 80 farmlands)

\begin{tabular}{l|rrrr}
\hline \multirow{2}{*}{\multicolumn{1}{c}{ Variables }} & \multicolumn{2}{c}{ GAP producers (41) } & \multicolumn{2}{c}{ Non-GAP producers (39) } \\
\cline { 2 - 5 } & Mean value & SD & Mean value & SD \\
\hline Type (0.1) & 0.63 & 0.49 & 0.36 & 0.48 \\
AGE (In Years) & 38.87 & 8.53 & 51.17 & 10.46 \\
EDUCATION (In Years) & 11.34 & 2.09 & 6.79 & 1.52 \\
Communication (0,1) & 0.46 & 0.50 & 0.31 & 0.46 \\
Seminars (0.1) & 0.53 & 0.50 & 0.23 & 0.42 \\
Family Tradition (0,1) & 0.22 & 0.41 & 0.79 & 0.41 \\
Agricultural Income ( () & 68.587 .6 & 58.863 .6 & 59.266 .9 & 40.803 .6 \\
\hline
\end{tabular}


As mentioned above, a measure for the goodness of fit test of the logit model is the correct classification of observations between producers that apply good agricultural practices and the ones that do not.

The result shows that $97.4 \%$ of the producers have been correctly predicted by the logit model to apply good agricultural practices. Similarly, $97.6 \%$ of the producers have been predicted correctly by the model not to apply good agricultural practices respectively. Only 2 producers were classified erroneously, and this result leads us to the conclusion that the logit model is very well fitted to the data, as it made correct predictions for $97.5 \%$ of the producers.

This conclusion is also verified by the Hosmer and Lemeshow test, where value $\chi^{2}=1.62$ corresponds to the significance level $\alpha=0.98$ which means that the model was well fitted to the data.

According to Table 3, the variables that affected statistically significantly (significance level 5.0\%) the implementation of Good Agricultural Practices and, consequently, the environmental awareness of the producers in a protected area (National Park) were the following: the cultivation of PGI products, the educational level of the producers, the communication and consultation of the producers with an agricultural engineer, the attendance of training seminars and the earned agricultural income.

More specifically: The variable named "Type" proved to affect the probability of applying good agricultural practices at a significance level of $2.4 \%$. More specifically, the Prespa beans producers who certified their product as a Protected Geographical Indication (PGI) one were 171 times more likely to work with greater environmental awareness, to implement GAP and to respect the protected area than the producers who did not certify their product as a PGI. This might happen because the ones certified as PGI producers worked in a way that satisfy the demands of the consumers for safer food, produced with environmentally friendly practices. On the contrary, the non-certified producers performed their agricultural activities without worrying whether their products fulfil the requirements of the consumers or not.

The results of the model showed that the educational level of the producers affected their environmental awareness. More specifically, if the years of education increase by 1 , the probability of applying GAP increase 14.99 times (odds ratio: 14.99). Consequently, the producers that had completed more years of education, being perhaps better informed about the consequences that the uncontrolled use of chemicals had on the environment, were more likely to perform their agricultural activity correctly than those with less years of education.

The producers who were informed by self-employed agricultural engineers and communicated often with them used pesticides and fertilizers in an uncontrolled way, and they were more likely not to apply GAP (probability of applying GAP: $1.0 \%$, odds ratio: 0.01 ) than the producers who did not communicate at all or rarely consult with selfemployed agricultural engineers. The reason for that was that many self-employed agricultural engineers owned shops of plant protection products and fertilizers. Therefore, they were mostly concerned with selling pesticides and fertilizers, and increasing their profit. These agricultural engineers did not seem to be very environmentally sensitive, and they sold their products thoughtlessly, without worrying about the real needs of the cultivations on chemicals, the protection of the environment from harmful elements and the production methods.

The variable "Seminars" was found to affect significantly enough the probability of applying agricultural practices that respect the environment. More specifically, the producers that had attended seminars concerning agriculture or the implementation of good agricultural and environmental practices were more likely (odds ratio: 100.2) to work with greater environmental awareness and respect for the area than those that had never attended seminars. The goal of these seminars was to promote environmental sensitivity and to disseminate knowledge on issues like solid waste management, the correct use of pesticides in agricultural products in order to protect the consumer and the environment, the environmentally sound management of water resources, etc. The producers got in-depth knowledge about the topics in question, and they formulated a mentality that enhances environmental awareness and protection.

The income the producers earned from bean agriculture was a negative factor for the implementation or not of good agricultural practices. That meant that if the bean agriculture income increased by one unit $(1 €)$, the probability of applying GAP was reduced by 0.99 (odds ratio: 0.99 ) or by $1.0 \%$. In other words, the producers that earned higher income from bean agriculture, compared to others, were less likely to apply GAP that respect the environment than the producers that earned lower income from bean agriculture. The reason for this was that the producers whose primary goal was to increase their profit and, consequently, to achieve higher economic results did not easily venture using alternative and more environmentally friendly production methods, because they believed that this attempt may reduce their production and, therefore, their profit.

The variables "Age" and "Family Tradition" had not proved to affect significantly (significance level $5.0 \%$ or $10 \%$ ), in terms of statistics, the decision of the producers to apply GAP.

The following table (Table 3 ) presents the results of the estimation of the regression equation (4) made by the Econometrics Program Stata 9.

\section{Conclusions}

In order to succeed in improving the quality of agriculture, the quality of agricultural procedures needs to be upgraded, which will eventually result in qualitative and competitive production. There is no doubt that the change towards quality production should take place under certified and supervised agricultural systems.

According to the descriptive statistics results, the producers that apply good agricultural practices are of a younger age, they have completed more years of education, they have attended seminars on agriculture, they are members of a cooperative, they cultivate more hectares of beans, and they have less work experience in agriculture than the producers with no concern for environmental issues. 
Table 3 Logit model results concerning the estimation of factors that affect the application of GAP in a protected area (National Park).

\begin{tabular}{l|cccc}
\hline \multicolumn{1}{c|}{ Independent Variables } & Odds Ratio & Robust Std. Error & $\mathrm{z}$ & $\mathrm{P}>\mathrm{z}$ \\
\hline Type & 171.07 & 388.73 & 2.26 & 0.024 \\
Age & 1.01 & 0.07 & 0.03 & 0.977 \\
Education & 14.99 & 192.52 & 3.90 & 0.000 \\
Communication & 0.01 & 0.02 & -2.57 & 0.010 \\
Seminars & 100.20 & 206.19 & 2.24 & 0.025 \\
Family Tradition & 0.03 & 0.09 & -1.34 & 0.181 \\
Agricultural Income & 0.99 & 0.01 & -2.03 & 0.043 \\
\hline N=80; Wald chi ${ }^{2}(9)=37.24 ;$ Prob $>$ chi $^{2}=0.000 ;$ Pseudo $\mathrm{R}^{2}=0.8672$ & & \\
\hline
\end{tabular}

The estimation of the logit model for the factors that affect the probability of adopting Good Agricultural Practices in a protected area showed that the personal features of the producers, their education or training and the possibility of being informed by agricultural engineers affect significantly the decision to adopt and implement GAP.

More specifically, the bean producers that certify their product as a Protected Geographical Indication (PGI) one are more likely to apply good agricultural practices with respect to the environment than the producers that do not certify their product as such.

Moreover, the education and vocational training of the producers affect the application of GAP in a positive way. Attending training seminars and more years of education increased the probability of adopting GAP.

On the contrary, the producers who have frequent communication with self-employed agricultural engineers and earn higher income from the bean agriculture compared to others are less likely to adopt and apply good agricultural practices.

The application of the Code of Good Agricultural Practice is an environmental measure that aims at balancing and moderating the negative consequences of agricultural activity upon the environment. Therefore, more attention needs to be paid on environmental issues and on encouraging the implementation of good agricultural practices with the aim to preserve the natural environment, ensure food safety and quality, and increase the productivity of farmers. Finally, it must be highlighted that the Code of Good Agricultural Practice (CoGAP) is a piece of legislation that imposes what should have been taken for granted, and what should be required of all of us.

\section{References}

Battary P, Dicks L, Kleijn D, Sutherland W. 2015. The role of agri-environment schemes in conservation and environmental management. Conservation Biology (29)4: 1006-1016.

Beletti J, Marescotti A, Touzard JM. 2017. Geographical Indications, Public Goods, and Sustainable Development: The Roles of Actors' Strategies and Public Policies. World Development 98: 45-57. https://prodinra.inra.fr/record /323932 [Accessed 20 May 2017]

Borowska A. 2010. The role of traditional and regional food products in rural development in Poland. Social Research 1(18): 40-52. http://www.su.lt/bylos/mokslo_leidiniai/ soc_tyrimai/2010_18/borowska.pdf [Accessed 15 May 2017]
Cramer JS. 2004. The early origins of the logit model. Studies in History and Philosophy of Biological and Biomedical Science 35: 613-626. https://www.sciencedirect.com/ science/article/pii/S1369848604000676?via\%3Dihub [Accessed 20 December 2016]

De Baerdemaeker J. 2013. Precision Agriculture Technology and Robotics for Good Agricultural Practices. In: IFAC Proceedings 46(4): 1-4. https://www.sciencedirect.com/ science/article/pii/S1474667016334942 [Accessed 10 December 2016]

Gujarati DN. 2003. Basic Econometrics. International Edition. New York: McGraw- Hill Companies. ISBN 0-07-112342-3.

Hajdukiewicz A. 2014. European Union agri-food quality schemes for the protection and promotion of geographical indications and traditional specialities: An economic perspective. Folia Horticulturae 26(1): 3-17. https://www.degruyter.com/downloadpdf/j/fhort.2014.26.iss ue-1/fhort-2014-0001/fhort-2014-0001.pdf [Accessed 20 January 2017]

Huttunen S, Peltomaa J. 2016. Agri-environmental policies and 'good farming' in cultivation practices at Finnish farms. Journal of rural studies 44: 217-226. https://www.sciencedirect.com/science/article/pii/S0743016 716300213[Accessed 15 April 2017]

IUCN. 2016. Protected Areas - what are they, why have them. http://www.iucn.org/about/work/programmes/gpap_home/pa s_gpap/. [Accessed 29 November 2016]

Ministry of Rural Development and Food. 2010. Codes of Good Agricultural Practice. http://www.minagric.gr/greek/ epaa/INDEX\%201/Aлó $\alpha \sigma\rceil \% 20$ КОГП.pdf. [Accessed 14 January 2016]

Ministry of the Environment, Energy and Climate Change. 2016. Protected Areas in Greece. http://www.ypeka.gr/Default.aspx ?tabid=433\&language $=$ el-GR $[$ Accessed 15 November 2016].

Parra-Lopez C, Calatrava-Requena J, De-Haro-Gimenez T. 2007. A multi-criteria evaluation of environmental performances of conventional, organic and integrated olive-growing systems in the south Spain based on experts knowledge. Renewable Agriculture and Food Systems 22(3): 189-203.

Municipality of Prespes. 2017. Natural Environment. Protected Areas. http://www.prespes.gr/prespa/index.php/2015-05-1016-03-39. [Accessed 14 January 2017]

Ramsar Wetlands International. Sites in Greece. http://ramsar.wetlands.org/Database/Searchforsites/tabid/76 5/language/en-US/Default.aspx, [Accessed 30/1/2017]

Siardos KG. 2005. Methods of multivariate statistical analysis

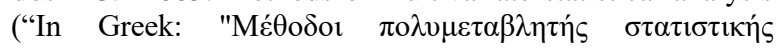

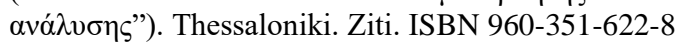

Vastola A. Pandi Z. D'Amico M. Pappalardo M. Vaccaro G. Di Napoli M. Cozzi F. Romano S. 2017. Comparative multidimensional evaluation of conservation agriculture systems: A case study from a Mediterranean area of Southern Italy. Land Use policy 68: 326 - 333. 